\title{
Nickel(II)-Complex of Ceftibuten Dihydrate: Synthesis, Characterization and Thermal Study
}

\author{
Shuchismita Dey ${ }^{1}$, Md. Zakir Sultan ${ }^{2}$ and Md. Abdus Salam ${ }^{1}$ \\ ${ }^{1}$ Department of Chemistry, University of Dhaka, Dhaka-1000, Bangladesh \\ ${ }^{2}$ Centre for Advanced Research in Sciences (CARS), University of Dhaka, Dhaka-1000, Bangladesh
}

(Received: November 1, 2021; Accepted: December 14, 2021; Published (web): December 26, 2021)

\begin{abstract}
Ceftibuten dihydrate is a semisynthetic, orally administered, third generation cephalosporin antibiotic which is effective against most of the pathogens causing infections in the respiratory tract. Complexation of ceftibuten dehydrate (Ligand, L) was performed with hydrated $\mathrm{Ni}(\mathrm{II})$ salt (Metal, M) in the ratio of 2:1 (L:M) in aqueous medium at $90{ }^{\circ} \mathrm{C}$. The metal complex was then characterized by spectral techniques and thermal analyses. The FT-IR spectral data of metal complex suggested the monodentate bonding of metal ion to carboxylate group. Spectral evidence also supported the formation of five-membered ring via coordination of metal ion to $\beta$-lactam nitrogen and carboxylate group of parent drug. Thermal behavior of ligand and complex were studied. Thus, thermoanalytical (DSC and TGA) results also supported the formation of new metal complex, indicating the successful interaction of metal ion to ligand.
\end{abstract}

Key words: Ceftibuten, Ni(II)- complex, Interaction, Thermal analyses.

\section{INTRODUCTION}

Drug research is an important field of medicinal chemistry. It includes new drug synthesis with therapeutic importance ${ }^{1-3}$, isolation of bioactive compounds from different parts of medicinal plants via solvent extraction ${ }^{4,5}$ and metal complexation of drug with improved bioactivity. ${ }^{6-8}$ Drug-drug interaction $^{9,10}$ is also an emerging field of drug research. Moreover, in advance study, computer aided design has been implemented to discover new drug. ${ }^{11}$

Presently metal complexation of drug is an important area of research in pharmaceutical chemistry. In this study, complexation of ceftibuten dihydrate has been performed using $\mathrm{Ni}(\mathrm{II})$ salt as metal source. Ceftibuten dihydrate is chemically (+)(6R,7R)-7-[(Z)-2-(2-amino-4-thiazoyl)-4-carboxycrotonamido]-8-oxo-5-thia-1-azabicyclo(4,2,0)oct-2-ene -2-carboxylic acid, dihydrate with molecular formula $\mathrm{C}_{15} \mathrm{H}_{14} \mathrm{~N}_{4} \mathrm{O}_{6} \mathrm{~S}_{2} 2 \mathrm{H}_{2} \mathrm{O}$ and molecular weight $446.45 .{ }^{12}$

Correspondence to: Md. Abdus Salam

Email: masalam@du.ac.bd

Dhaka Univ. J. Pharm. Sci. 20(2): 219-225, 2021 (December)

DOI: https://doi.org/10.3329/dujps.v20i2.57172
It is a class of $\beta$-lactam, orally administered third generation cephalosporin antibiotic, effective against the most of the pathogens causing infections in the respiratory tract. ${ }^{13}$ Ceftibuten dihydrate belongs to bactericidal antibiotic that kills bacteria through binding of essential target protein of bacterial cell wall and thus inhibits replication. ${ }^{14}$

Literature survey showed that metal complexes of nitrogen containing ligands possess a variety of range of biological properties such as antibacterial, antifungal, antitumor and antiviral activities. ${ }^{15-17}$ Actually the lipophilicity of parent ligand is increased through the complexation with metal ions and thus boost up the penetration capability of the ligand into the lipid membrane of bacteria. As a result, new cell wall formation is greatly hampered. Without a cell wall, a bacterial cell is defenseless to outside water and molecular pressures, which causes the cell to die quickly. ${ }^{18,19}$ Thus, the antimicrobial activity of ligands can be improved through chelation. ${ }^{20}$ Even some inactive ligands may acquire pharmacological properties upon chelation. ${ }^{21}$ From the literature survey, it is also revealed that pharmacologically 
important metals like copper, nickel, magnesium, cobalt, chromium and zinc are widely used for complexation and thus, playing a vital role in the development of treatment of various life threatening infectious diseases. ${ }^{22}$ In searching of more potent chemotherapeutic agent, researchers have also introduced mixed ligand complexes. ${ }^{23}$ Recently, an article on $\mathrm{Cu}$ (II)-complex of ceftibuten dihydrate has been reported from our group. ${ }^{24}$ In that work, $\mathrm{Cu}$ (II) salt was used as metal source. In current study, $\mathrm{Ni}$ (II) complex of ceftibuten dihydrate was synthesized as stated by the methods reported in previous article. After that the newly synthesized metal complex was characterized by using spectral techniques like FT-IR and thermal analyses like DSC and TGA.

\section{MATERIALS AND METHODS}

Instrumentation. Development of new drugmetal complex was verified by several analytical techniques like melting point determination, FT-IR spectra, DSC and TGA. Melting point of pure drug and its $\mathrm{Ni}(\mathrm{II})$-complex were recorded by working with digital melting point apparatus (WRS-1B). FTIR spectrophotometer (Model: 8400s, Shimadzu, Japan) was used to acquire FT-IR spectra. The spectra were taken as $\mathrm{KBr}$ discs in the region of 4000-400 $\mathrm{cm}^{-1}$. DSC studies were performed in aluminum sealed pan at the temperature range of 20$700^{\circ} \mathrm{C}$ by using DSC instrument (Model: DSC 131 EVO, Setaram Instrumentation, France). $\mathrm{N}_{2}$ gas flow rate and temperature rising rate were kept at 20 $\mathrm{ml} / \mathrm{min}$ and $10^{\circ} \mathrm{C} / \mathrm{min}$, respectively to record the thermograms. TGA studies were carried out for both ligand and chelate using TGA 50H (Shimadzu, Japan). The thermograms were recorded at the region of $25-800{ }^{\circ} \mathrm{C}$ in aluminum pan, maintaining at 10 ${ }^{\circ} \mathrm{C} / \mathrm{min}$ and $10 \mathrm{~mL} / \mathrm{min}$ heat and $\mathrm{N}_{2}$ gas flow rate, respectively.

Materials. The drug was collected from Incepta Pharmaceutical Ltd., Dhaka, Bangladesh as a gift. The potency of the drug was about $99 \%$. Nickel(II) chloride $\left(\mathrm{NiCl}_{2} \cdot 6 \mathrm{H}_{2} \mathrm{O}\right)$ was used as metal source to make coordinate complex. The solvents and other chemicals were procured from the local suppliers.
Synthetic procedure for complexation with $\mathrm{Ni}$ (II) salt. To verify the synthetic route as reported earlier $^{24}$, the $\mathrm{Ni}(\mathrm{II})$-complex of ceftibuten dihydrate was prepared by maintaining same $\mathrm{pH}$, solvent and temperature of reaction according to scheme- 1 . The ratio of ligand and metal in the complex formation was maintained at 2:1. A colored precipitated was obtained after complexation, which was also purified following same procedure as like $\mathrm{Cu}$ (II)-complex of ceftibuten dihydrate. ${ }^{24}$ The complex was found to be air and moisture stable, dissolved in aqueous medium at $90^{\circ} \mathrm{C}$ and organic solvent DMSO, not dissolved in common organic solvents like methanol, ethanol, acetonitrile, acetone and diethyl ether. Yield was obtained as $75 \%$ and recorded m.p. was $305^{\circ} \mathrm{C}$ (decomposed).
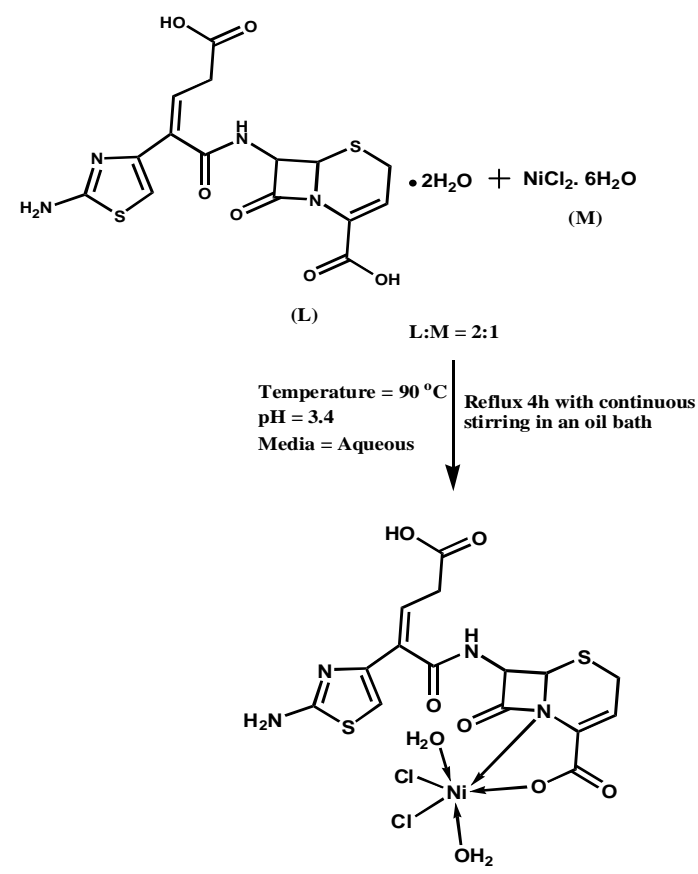

Scheme 1. Synthetic scheme for complexation of ceftibuten dihydrate with $\mathrm{NiCl}_{2} \cdot 6 \mathrm{H}_{2} \mathrm{O}$.

\section{RESULTS AND DISCUSSION}

Thermal analysis. Both TGA and DSC analyses of pure drug, ceftibuten dihydrate and its metal complexes were studied to explore thermal stability as well as to establish melting point. ${ }^{25,26}$ The TGA and DSC data are summarized in Table 1. 
Table 1. Thermo analytical results of parent drug and its metal complexes.

\begin{tabular}{llll}
\hline Compound & $\begin{array}{l}\text { Temperature } \\
\text { of TGA }\left({ }^{\circ} \mathrm{C}\right)\end{array}$ & $\begin{array}{l}\text { Weight } \\
\text { loss }(\%) \\
\text { Found }\end{array}$ & $\begin{array}{l}\text { DSC Temp. } \\
\left({ }^{\circ} \mathrm{C}\right)\end{array}$ \\
\hline $\begin{array}{l}\text { Ceftibuten } \\
\text { dihydrate }\end{array}$ & $20-176$ & 9.8 & 98 \\
(Parent drug) & $176-396$ & 55.8 & endothermic \\
& $396-630$ & 91.8 & $\begin{array}{l}242.7 \\
\text { exothermic }\end{array}$ \\
\hline Ni(II) & $630-800$ & 93.6 & 89.3 \\
complex & $20-171$ & 10.8 & endothermic \\
(Present & $171-394$ & 41.3 & $219.7,308$ \\
work) & $394-609$ & 79.9 & endothermic \\
\hline Cu(II) & $609-800$ & 83.3 & 86.7 \\
complex & $25-175$ & 8.32 & endothermic \\
(Reported) ${ }^{12}$ & $175-311$ & 34.7 & 269.2 \\
& $311-507$ & 75 & endothermic \\
\hline
\end{tabular}

Thermogravimetric analysis (TGA). The structure of metal antibiotic complex can be proposed by using TGA. ${ }^{27}$ Pure drug and its metal complexes showed multistage degradation profiles where mass changes were observed at $25^{\circ} \mathrm{C}$ and continued up to $800^{\circ} \mathrm{C}$ with increasing temperature. The resulting TGA curves of pure drug and its $\mathrm{Ni}$ (II) chelate are shown in Figure 1. Hydrated metal salts are usually used for coordination of drugs. In case of hydrated complex, water loss always takes place relatively at higher temperature (above $150^{\circ} \mathrm{C}$ ) than uncoordinated complex. ${ }^{28}$ Kumar et al. showed similar degradation

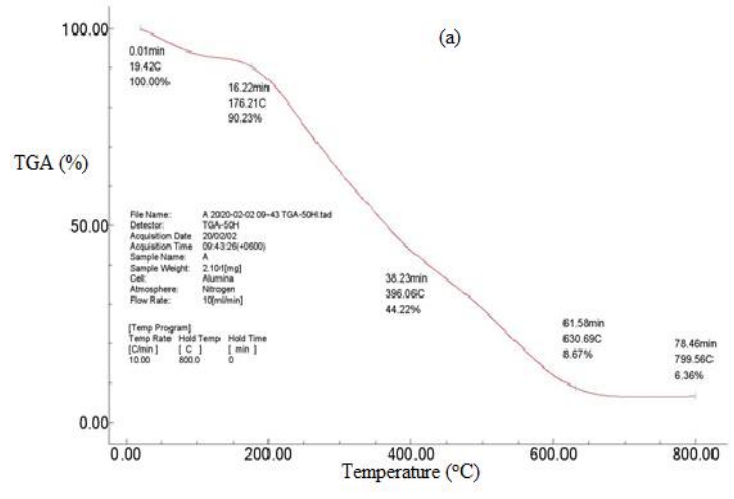

pattern in TGA curve of $\mathrm{Fe}$ (II) and $\mathrm{Ni}$ (II) complex of penicillin $\mathrm{G}$ and ciprofloxacin. ${ }^{29}$ Tahia et al. also showed a different degradation pattern of metallodrug, from its parent drug, levofloxacin. ${ }^{17}$ In present study, a weight loss of $9.77 \%$ was found in TGA of pure drug at $176.21^{\circ} \mathrm{C}$, corresponding to loss of water molecules. After that $55.78 \%$ weight loss was found at $396^{\circ} \mathrm{C}, 91.33 \%$ at $630^{\circ} \mathrm{C}$ and finally $93.64 \%$ weight loss was observed at $800^{\circ} \mathrm{C}$. The drug-metal complex also showed multistage degradation pattern, starting with release of water molecules. The degradation pattern of metal complexes is completely different from parent drug, suggesting the successful interaction of drug and metal ion. In case of $\mathrm{Ni}(\mathrm{II})$-complex of parent drug, weight loss was found as $10.78 \%, 41.29 \%, 79.93 \%$ and finally $83.34 \%$ at $171^{\circ} \mathrm{C}, 394^{\circ} \mathrm{C}, 609^{\circ} \mathrm{C}$ and $800^{\circ} \mathrm{C}$, respectively. It is noted that the complex possessed better thermal stability compared to parent drug, and a residual mass was obtained even after heating to $800^{\circ} \mathrm{C}$. Ali et al. reported similar multistage degradation pattern in case of metal(II) complexation of flucanozole, starting with initial loss of water molecule followed by removal of ligand moiety. ${ }^{25}$

Figure 1. TGA thermograms of ceftibuten dihydrate (parent drug) (a), ceftibuten-Ni(II) complex (b).

Differential scanning calorimetry (DSC). The DSC curves recorded for parent drug and its complexes are shown in Figure 2. The DSC result of pure drug showed an endothermic peak at $98^{\circ} \mathrm{C}$

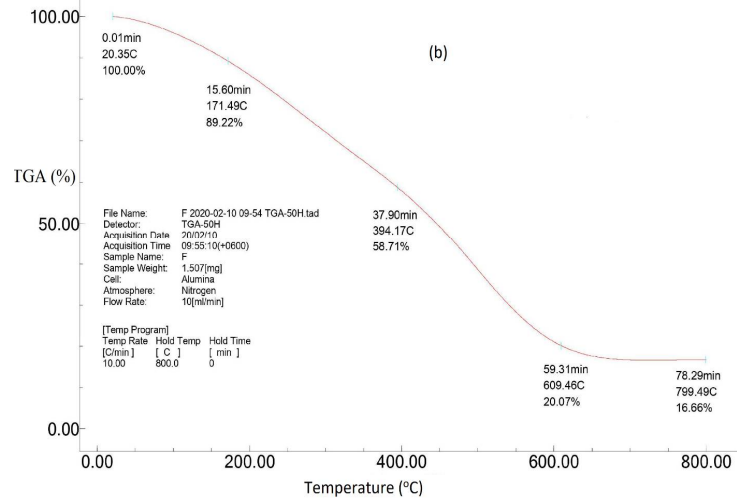

associated with dehydration of water molecules, and an exothermic peak at $242.7^{\circ} \mathrm{C}$ which corresponded to its melting point. The calorimetric curve of $\mathrm{Ni}(\mathrm{II})$ complex of parent drug showed three endothermic 
peaks. An endothermic peak at $89.35^{\circ} \mathrm{C}$ is associated with removal of water molecules. Another peak (endothermic) obtained at $219.76^{\circ} \mathrm{C}$ might be due to sample mass loss or sample phase transition. One more peak (endothermic) found at $308.35^{\circ} \mathrm{C}$, considered as melting temperature of the complex. The absence of melting peak $\left(242.7^{\circ} \mathrm{C}\right)$ of pure drug in the calorimetric curve of the complexes indicated that the drug metal interaction occurred which resulted in new and definite compound without the interference of starting materials. Similar findings in the DSC curve were obtained in the metal(II) complexation of fluconazole ${ }^{25}$, Schiff base ligand derived from hydrazine benzoxazine ${ }^{30}$, and 14, 15 and 16-membered macrocyclic ligands. ${ }^{31}$ In case of

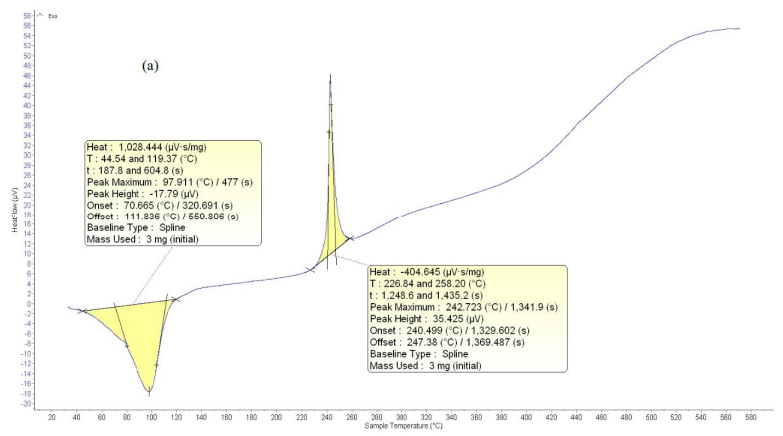

$\mathrm{Ni}$ (II) complexation of Schiff base ligand derived from hydrazine benzoxazine, the authors found an endothermic peak at $108.62^{\circ} \mathrm{C}$ in DSC curve, corresponding to loss of hydrated water molecule. Another two peaks at $177.13^{\circ} \mathrm{C}$ for phase transition and at $322^{\circ} \mathrm{C}$ corresponding to melting were also reported.

FT-IR analysis. Formation of a new coordination complex as well as the binding site of ligand to metal ion were elucidated by analyzing FTIR spectra. Any shifts in frequency or appearance of new peaks indicated the formation of new compound, different from starting material. The main vibrational frequencies of parent drug and its metal chelates are summarized in Table 2.

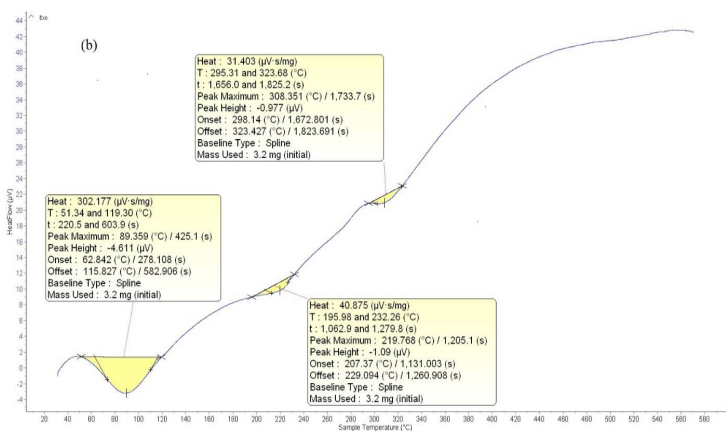

Figure 2. DSC thermograms of ceftibuten dihydrate (parent drug) (a), ceftibuten-Ni(II) complex (b).

Table 2. Characteristic FT-IR frequencies $\left(\mathrm{cm}^{-1}\right)$ for parent drug and its metal complexes.

\begin{tabular}{|c|c|c|c|c|c|c|}
\hline Compound & $\begin{array}{l}v(\mathrm{CO}) \\
\text { lactam }\end{array}$ & $\begin{array}{l}v\left(3^{\circ} \mathrm{N}\right) \\
\text { lactam }\end{array}$ & $\begin{array}{l}v(\mathrm{COO}) \\
\text { asymmetric }\end{array}$ & $\begin{array}{l}v(\mathrm{COO}) \\
\text { symmetric }\end{array}$ & $\Delta v$ & $v(\mathrm{M}-\mathrm{N})^{*}$ \\
\hline $\begin{array}{l}\text { Ceftibuten dihydrate } \\
\text { (Parent drug) }\end{array}$ & 1770 & 1361 & 1651 & 1415 & 236 & - \\
\hline $\begin{array}{l}\mathrm{Ni}(\mathrm{II}) \text {-complex } \\
\text { (Present work) }\end{array}$ & 1759 & 1103 & 1624 & 1398 & 222 & 478 \\
\hline $\mathrm{Cu}(\mathrm{II})-$ complex $^{24}$ & 1755 & 1114 & 1629 & 1402 & 227 & 476 \\
\hline
\end{tabular}

*M-N indicates the Metal-Nitrogen coordination bonding.

It was reported the formation of coordination complexes of different ligands by examining FT-IR spectra. ${ }^{31,32}$ Figure 3 shows that in the FT-IR spectra of parent drug (free ligand) as well as its $\mathrm{Ni}(\mathrm{II})$ chelate, significant changes in the frequency of absorbed radiation, characteristic of different functional groups of free ligand were observed due to interaction with metal ion. Analyzing IR data of ceftibuten dihydrate (Figure 3a), it was found that lactam $(\mathrm{C}=\mathrm{O})$ and carboxyl $(\mathrm{C}=\mathrm{O})$ bands appear at 1770 and $1651 \mathrm{~cm}^{-1}$, respectively. Like $\mathrm{Cu}(\mathrm{II})$ complex $^{24}$ of ceftibuten dihydrate, significant changes in the frequency of lactam $(\mathrm{C}=\mathrm{O})$ was not observed in $\mathrm{Ni}(\mathrm{II})$-complex of pure drug as well. It means that the carbonyl group of lactam ring was not involved in the formation of coordination complexes 
of ceftibuten dihydrate. The non-participation of lactam $(\mathrm{C}=\mathrm{O})$ in the formation of coordination complexes was observed in case of cefixime with copper ion complex ${ }^{33}$ and penicillin $\mathrm{G}$ with iron(III) ion complex. ${ }^{29}$ Sultana et al. also reported the noninvolvement of lactam $(\mathrm{C}=\mathrm{O})$ in case of different metal complexes of cephradine. ${ }^{34,35}$ In $\mathrm{Ni}(\mathrm{II})$ - complex, another two significant peaks appearing at 1624 and $1398 \mathrm{~cm}^{-1}$ are due to $v_{\text {asym }} \mathrm{COO}$ - and $v_{\text {sym }} \mathrm{COO}$ - stretching bands, respectively (Figure $3 \mathrm{~b}$ ). In this study, the separation value, $\Delta v>200 \mathrm{~cm}^{-1}(\Delta v$ $=v_{\text {asym }}-v_{\text {sym }}$ ) confirms monodentate fixing of metal ion with carboxylate group present in parent drug. ${ }^{29,36}$
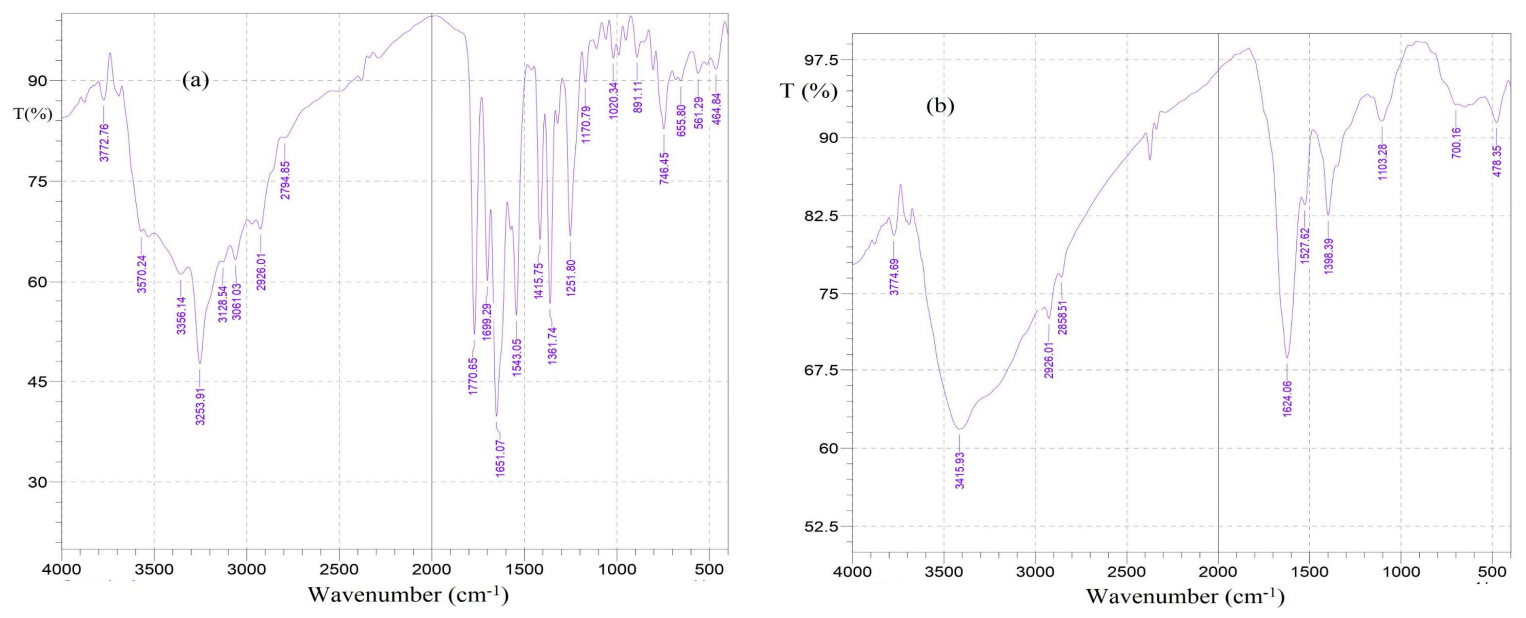

Figure 3. FT-IR spectra of ceftibuten dihydrate (parent drug) (a), ceftibuten-Ni(II) complex (b).

The frequency of $3^{\circ} \mathrm{N}$ atom present in $\beta$-lactam ring of parent drug is shifted $\left(1361 \rightarrow 1103 \mathrm{~cm}^{-1}\right)$ in the complex, due to involvement of $3^{\circ} \mathrm{N}$ atom in chelation. $^{24,34,35}$ There was a new peak found at 478 $\mathrm{cm}^{-1}$ in the FT-IR spectrum of the complex [Figure 3(b)] which was due to $v(\mathrm{Ni}-\mathrm{N}){ }^{32}$ El Tabl et al. reported a peak at $480 \mathrm{~cm}^{-1}$ for $\mathrm{Ni}-\mathrm{N}$ bond in $\mathrm{Ni}(\mathrm{II})-$ complexes of L-amino acids, used as foliar fertilizers. The M-N stretching vibration appearing at $478 \mathrm{~cm}^{-1}$ supports the formation of coordination complex through $\mathrm{N}$ atom in $\beta$-lactam ring. The FT-IR spectrum of the coordinated complex showed a broad band in the region of $3100 \sim 3600 \mathrm{~cm}^{-1}$ giving evidence of coordinated water present in the metal complex..$^{37}$ The presence of coordinated water was also identified in the cadmium (II) complex of tolfenamic acid by Salekin et $a l .{ }^{38} \mathrm{~A}$ peak at about $3313 \mathrm{~cm}^{-1}$ confirmed the presence of coordinated water in cadmium (II) complex of tolfenamic acid. In present study, the thermoanalytical results of metal complex also supported the presence of coordinated water in the complex. Therefore, both spectroscopic and thermal results stated the evidence for the formation of new $\mathrm{Ni}(\mathrm{II})$-complex of ceftibuten dihydrate. Spectral studies indicated the coordination of $\mathrm{Ni}$ (II) ion through $\beta$-lactam nitrogen and carboxylate oxygen of drug molecule forming a fivemembered ring (Scheme-1). In above mentioned complexes it was suggested monodentate coordination of metal ions to carboxylate group, according to the report ${ }^{36}$ published previously as $\Delta v>$ $200 \mathrm{~cm}^{-1}\left(\Delta v=v_{\text {asym } \mathrm{COO}^{-}}-v_{\text {sym }} \mathrm{COO}^{-}\right)$which was supportive evidence of the scheme.

\section{CONCLUSION}

Ceftibuten-Ni(II) complex was synthesized from drug metal interaction of ceftibuten dehydrate with $\mathrm{NiCl}_{2}$ in aqueous medium at $90^{\circ} \mathrm{C}$ and then characterized. Both spectral and thermoanalytical results confirmed the new metal complex formation. The FT-IR spectrum of metal complex showed significant changes in the frequency of absorbed radiation, characteristic of different functional groups of free ligand, suggesting the formation of complex. 
The DSC and TGA results also supported the formation of the complex.

\section{ACKNOWLEDGEMENT}

The authors are grateful to the Bose Centre for Advanced Study and Research in Natural Sciences, University of Dhaka, Bangladesh to support this project.

\section{REFERENCES}

1. Reza, A.F.G.M., Khan, M.W., Rahman M.S., Chowdhury, M.H. and Rashid, M.A. 2006. In vitro antimicrobial activity of some synthetic isoindolinone and isoquinolinone derivatives. Dhaka Univ. J. Pharm. Sci. 5, 15-19.

2. Saha, P., Bristy, S.R., Rahman S.M.A. 2021. Pharmacological screening of substituted benzimidazole derivatives. Dhaka Univ. J. Pharm. Sci. 20, 95-102.

3. Afzal, M., Sultan, M.Z., Begum, R., Rahman, A., Sultana, S., Amran M.S. and Hossain, M.A. 2012. In vitro interaction of nandrolone with calcium nitrate, magnesium sulfate and potassium permanganate in aqueous medium. Dhaka Univ. J. Pharm. Sci. 11, 93-99.

4. Ahsan, M.R., Sultan, M.Z., Baki, M.A., Rahman, M.A. Hossain, M.A. Hossain, M.A. and Amran, M.S. 2011. The study of in vitro and in vivo effect of concurrent administration of paracetamol and zinc on the antibacterial activity of ciprofloxacin. Dhaka Univ. J. Pharm. Sci. 10, 37-142.

5. Moniruzzaman, M., Kuddus, M.R., Haque, M.R., Chowdhury, A.M.S. and Rashid, M.A. 2018. Stereospermum suaveolens (Roxb.) DC. shows potential in vivo and in vitro bioactivities. Dhaka Univ. J. Pharm. Sci. 17, 257-263.

6. Aktar, F., Sultan, M. Z. and Rashid, M.A. 2021. Chromium (III) complexes of metformin, dapagliflozin, vildagliptin and glimepiride potentiate antidiabetic activity in animal model. Int. J. Curr. Res. Rev. 13, 64-69.

7. Tahia, F., Sultan, M.Z., Islam, M.K. and Rashid, M.A. 2019. Thermochemical properties and bioactivity of the metallic complexes of levofloxacin. Asian J. Org. Med. Chem. 4, 89-93.

8. Sukul, A., Das, S.C., Saha, S.K. and Rahman, S.M.A. 2014. Screening of analgesic, antimicrobial, cytotoxic and antioxidant activities of metal complexes of indomethacin. Dhaka Univ. J. Pharm. Sci. 13, 175-180.

9. Hossain, M.J., Sultan, M.Z., Rashid, M.A. and Kuddus, M.R. 2020. Does rabeprazole sodium alleviate the antidiabetic activity of linagliptin? Drug-drug interaction analysis by in vitro and in vivo methods. Drug Res.70, 519-527.

10. Aktar, F., Sultan, M.Z. and Rashid, M.A. 2019. In vitro complexation of olmesartan medoxomil with dapagliflozin, vildagliptin and metformin. Dhaka Univ. J. Pharm. Sci. 18, 271-280.
11. Akter, S., Khan, M.F, Rahman, M.M. and Rashid, M.A. 2016 Computational study of geometry, polarizability, hyperpolarizability and molecular docking studies of naproxen. Dhaka Univ. J. Pharm. Sci. 15, 37-45.

12. Hathiram, B.T., Grewal, D.S., Tankwal, P., Shah, N., Agarwal, R. 1999. Ceftibuten in ENT infections. Indian J. Otolary. Head \& Neck Surg. 51, 104-107.

13. Watanabe, A., Oizumi, K., Motomiya, M., Yoshida, T., Ito, T., Kanayama, H., Saito, J., Nakai, Y., Sato, K. 1990. Therapeutic efficacy of ceftibuten in chronic respiratory tract infections. Jpn. J. Antibiot. 43, 768-778.

14. Tomasz, A. 1979. The mechanism of the irreversible antimicrobial effects of penicillins: How the beta-lactam antibiotics kill and lyse bacteria. Annu. Rev. Microbiol. 33, 113-137.

15. Pedrares, A.S., Romero, J., Vazquez, J.A.G., Duran, M.L., Casanova, I. 2003. Electrochemical synthesis and structural characterisation of zinc, cadmium and mercury complexes of heterocyclic bidentate ligands (N, S). Dalton Trans.7, 13791388.

16. El-Asmy, A.A., Khalifa, M.E., Hussain, M.M. 2004. Synthesis and characterization of transition metal complexes containing oxime, amido and thioamido groups. Indian J. Chem. 43A, 92-97.

17. Ekegren, J. K., Rath, P., Kallostrom, K., Tarnai, T., Anderson, P. G. 2003. Synthesis and evaluation of $N, S$-compounds as chiral ligands for transfer hydrogenation of acetophenone. Org. Biomol. Chem. 1, 358-366.

18. Tweedy, B.G. 1964. Plant extracts with metal ions as potential antimicrobial agents. Phytopathol. 55, 910-918.

19. Anjaneyulu, Y., Prabhakara Rao, R. 1986. Preparation, characterization and antimicrobial activity studies on some ternary complexes of $\mathrm{Cu}(\mathrm{II})$ with acetylacetone and various salicylic acids, synthesis and reactivity in inorganic and metalorganic chemistry, Synth. React. Inorg. Met. Org. Chem. 16, 257- 272.

20. Zhang, C.X., Lippard, S. 2003. New metal complexes as potential therapeutics. J. Curr. Opin. Chem. Biol. 7, 481-489.

21. Abu-Hussen, A.A.A., Emara, A.A.A. 2004. Metal complexes of some thiocarbohydrazone ligands: synthesis and structure. J. Coord. Chem. 57, 973-987.

22. Uivarosi, V. 2013. Metal complexes of quinolone antibiotics and their applications: An update. Molecules 18, 11153 11197.

23. Hossain M.B., Hassan, M.Z., Yousuf, M.A. and Salam, M.A. 2008. Antimicrobial activity studies of mixed ligand metal complexes of some dibasic acid and heterocyclic bases. Dhaka Univ. J. Pharm. Sci. 7, 145-148.

24. Dey, S., Sultan, M.Z., Salam, M.A. 2021. Synthesis, characterization of ceftibuten-copper(II) complex and prediction of its biological activity. Asian J. Chem. 33, 190-194. 
25. Ali, S. I., Lei, Z.N., Ali, M., Kojima, K., Ahmed, M., Peng, R., Yang, D.H., Haider, S.M., Ayatollahi, S.A.M. and Chen, Z.S. 2020. Metal(II) complexes of fluconazole: Thermal, XRD and cytotoxicity studies. Iranian J. Pharm. Res. 19, 171-182.

26. Haines, P.J., Reading, M., Wilburn, F.W. 1998. In: Handbook of Thermal Analysis and Calorimetry, (Brown M.E., Eds.), Elsevier Science, The Netherlands BV; pp. 279.

27. Ramotowska, S., Małgorzata, W., Brzeski, J., Chylewska, A. and Makowski, M. 2020. A comprehensive approach to the analysis of antibiotic-metal complexes. TrAC Trends Anal. Chem. 123, 115771.

28. Al-Khodir, F.A.I. and Refat, M.S. 2015. Synthesis, structural characterization and biological studies of some nalidixic acidmetal complexes: metalloantibiotic complexes of some divalent and trivalent metal ions. J. Mol. Struc. 1094, 22-35.

29. Kumar, M., Sodhi, K.K., Singh, P., Agrawal, P.K. and Singh, D.K. 2019. Synthesis and characterization of antibiotic-metal complexes $\left[\mathrm{FeCl}_{3}(\mathrm{~L} 1)_{2} \mathrm{H}_{2} \mathrm{O}\right.$ and $\left.\mathrm{Ni}\left(\mathrm{NO}_{3}\right)_{2}(\mathrm{~L} 2)_{2} \mathrm{H}_{2} \mathrm{O}\right]$ and enhanced antibacterial activity. Environ. Nano. Monit. Manag. 11, 100209 .

30. Kavitha, N. and Lakshmi, P.V.A. 2017. Synthesis, characterization and thermogravimetric analysis of $\mathrm{Co}$ (II), $\mathrm{Ni}(\mathrm{II}), \mathrm{Cu}(\mathrm{II})$ and $\mathrm{Zn}(\mathrm{II})$ complexes supported by ONNO tetradentate Schiff base ligand derived from hydrazino benzoxazine. J. Saudi Chem. Soc. 21, S457-S466.

31. El-Tabl, A.S. 2004. Synthesis and characterization of Cobalt(II)/(III), Nickel(II) and Copper(II) complexes of new 14, 15 and 16-membered macrocyclic ligands. Bull. Korean Chem. Soc. 25, 1757-1763.
32. El-Tabl, A.S., El-Kousy, S., Wahba, M.A. and Khalefa, S.M. 2014. Organic amino acids chelates; preparation, spectroscopic characterization and applications as foliar fertilizers. $J$. $A d v$. Chem.10, 2203-2217.

33. Pillai, S. and PushpaLatha, S. 2016. Designing of some novel metallo antibiotics tuning biochemical behaviour towards therapeutics: Synthesis, characterisation and pharmacological studies of metal complexes of cefixime. J. Saudi Chem. Soc. 20, S60-S66.

34. Sultana, N., Arayne, M.S. and Afzal, M. 2003. Synthesis and antibacterial activity of cephradine-metal complexes: Part I complexes with magnesium, calcium, chromium and manganese. Pak. J. Pharm. Sci. 16, 59-72.

35. Sultana, N., Arayne, M.S. and Afzal, M. 2005. Synthesis and antibacterial activity of cephradine metal complexes: Part II complexes with cobalt, nickel, copper, zinc and cadmium. Pak. J. Pharm. Sci. 18, 36-42.

36. Deacon, G.B. and Phillips, R.J. 1980. Relationships between the carbon-oxygen stretching frequencies of carboxylate complexes and the type of carboxylate coordination. Coord. Chem. Rev. 33, 227-250.

37. Munde, A.S., Jagdale, A.N., Jadhav, S.M. and Chondhekar, T.K. 2009. Synthesis and characterization of some transition metal complexes of unsymmetrical tetradentate Schiff base ligand. J. Korean Chem. Soc. 53, 407- 414.

38. Salekin, S., Sharmin, T. and Rahman, M.S. 2020. Synthesis, characterization and analgesic activity of cadmium(II) complex of tolfenamic acid. Dhaka Univ. J. Pharm. Sci. 19, 59-64. 